\title{
Benefits of using a mobile application in learning a foreign language
}

Judith Bustillo / yudybg@hotmail.com

Claribel Rivera / claribera@yahoo.com

Juan Genaro Guzmán / juan.guzman02@usc.edu.co

Lizeth Ramos Acosta / Iramos@usc.edu.co

Universidad Santiago de Cali, Colombia

ABSTRACT This article aims to show how the use of a mobile application contributes to the development of listening comprehension in English as a teaching strategy to generate significant learning. The research was conducted with a group of level A1 students, according to Common European Framework for Languages: Learning, Teaching, Assessment, who used Duolingo during an academic semester. The results indicate that the use of this application achieves a positive impact on the development of listening skills in English.

KEYWORDS Gamification; learning; listening comprehension; English.

Beneficios del uso de una aplicación móvil en el aprendizaje de una lengua extranjera

RESUMEN El presente artículo tiene como objetivo mostrar cómo el uso de una aplicación móvil contribuye en el desarrollo de la comprensión auditiva en inglés como estrategia de enseñanza para generar aprendizaje significativo. La investigación se realizó con un grupo de estudiantes del nivel A1, de acuerdo con el Marco Común Europeo para el Aprendizaje de Lenguajes, quienes usaron Duolingo durante un semestre académico. Los resultados indican que el uso de dicha aplicación logra un impacto positivo en el desarrollo de la habilidad de escucha en inglés.

PALABRAS CLAVE Gamificación; aprendizaje; competencia auditiva; inglés.
Benefícios do uso de um aplicativo móvel na aprendizagem de uma língua estrangeira

RESUMO Este artigo tem como objetivo mostrar a forma em que o uso de um aplicativo móvel contribui para o desenvolvimento da compreensão oral em Inglês como estratégia de ensino para gerar uma aprendizagem significativa. A pesquisa foi realizada com um grupo de estudantes do nível Al segundo o Quadro Europeu Comum de Referência para Línguas, que utilizaram Duolingo durante um semestre letivo. Os resultados indicam que a utilização deste aplicativo tem um impacto positivo sobre o desenvolvimento da capacidade de escuta em Inglês.

PALAVRAS-CHAVE Gamificação ; aprendizagem; competência auditiva; Inglês. 


\section{Introduction}

This article is the result of the research project named: how do mobile applications help in the development of listening comprehension as a teaching strategy to generate significant learning of students at the Language Institute of the Universidad Santiago de Cali? developed as the thesis in the English Teaching Specialization in the same university [USG].

The USC, through the languages institute, had about 5,000 students in 2015. All the courses of foreign languages have an intensity of three face-to-face hours and six hours of independent work from the students. In these latter, the students have a varied offer of support activities as conversation clubs, tutorials, and idioms labs. Additionally, the professors of the institute suggest to the students the use of virtual tools to improve their communicative competence.

One of the challenges for the professors is to create consideration in the students about the importance of the constant practice for the development of abilities in foreign languages; specifically, in the listening comprehension. To address this, the professors employ in class some listening exercises of a guide CD that acts as a complement of the guide text.

The group of researchers that wrote this article considers that the use of the technology might be a way to encourage the students to improve the listening comprehension, even more considering the increasing popularity of the mobile devices in the academic population.

Currently, the use of the mobile technology has been increased in a considered way thanks to the ease of use and low cost of the applications focused on the learning of foreign languages. There is a wide variety of applications such as for the development of linguistic competences, listening, in reading, and writing. Amongst them, the group selected Duolingo as a tool to improve the listening comprehension of the students.

Duolingo has around 80 million users around the world for the learning of the English language; its method sets daily learning goals, allows the execution of an initial test to establish the level the user should start, and it uses images, translating and listening exercises. The group of students who used the application was also surveyed to know their opinion about the use of that tool and their benefits in the learning of English.

\section{Introducción}

Este artículo es el resultado del proyecto de investigación titulado: How do mobile applications help in the development of listening comprehension as a teaching strategy to generate significant learning of students at the Language Institute of Universidad Santiago de Cali?, desarrollado como trabajo de grado en la Especialización en Enseñanza de Inglés de la Universidad Santiago de Cali [USC].

La USC, a través del Instituto de Idiomas, atendió, en 2015, a una población aproximada de cinco mil estudiantes. Todos los cursos de lengua extranjera cuentan con una intensidad de tres horas presenciales y seis horas de trabajo independiente de los estudiantes, dentro de estas últimas los aprendientes cuentan con una oferta variada de actividades de apoyo como: club de conversación, tutorías y laboratorio de idiomas. Adicionalmente, los docentes del Instituto sugieren a sus estudiantes el uso de herramientas virtuales para el mejoramiento de la competencia comunicativa.

Uno de los retos para los profesores es crear conciencia en los estudiantes sobre la importancia de la práctica constante para el desarrollo de habilidades en la lengua extranjera, específicamente la comprensión auditiva, para abordarlo, los docentes utilizan, durante las clases, ejercicios de escucha de un CD que sirve como complemento al texto guía.

El grupo de investigadores autor de este artículo consideró que el uso de la tecnología podría ser una manera de motivar a los estudiantes para mejorar la comprensión auditiva, más aún considerando la enorme popularidad de dispositivos móviles entre la población estudiantil.

Actualmente, el uso de tecnología móvil se ha incrementado de manera vertiginosa gracias al fácil acceso y el bajo costo de las aplicaciones disponibles para la práctica de los idiomas. Existe una amplia variedad, hay aplicativos para el desarrollo de competencias lingüísticas, auditivas, en escritura y en lectura-, de ellas, el grupo seleccionó Duolingo, como herramienta para mejorar la comprensión auditiva de los estudiantes.

Duolingo cuenta con alrededor de ochenta millones de usuarios alrededor del mundo (para el aprendizaje del inglés); su método fija metas diarias de aprendizaje, permite la realización de una prueba inicial para establecer el nivel del usuario y utiliza imágenes, ejercicios de traducción y escucha. El grupo de estudiantes que utilizó la aplicación también fue encuestado con el fin de conocer su apreciación sobre el uso de dicha herramienta y su beneficio en el aprendizaje del inglés.

En este artículo se presenta una breve conceptualización acerca de la comprensión auditiva, la noción de gamificación y su uso en contextos de enseñanza; le sigue la descripción de la metodología y los hallazgos obtenidos en su aplicación; y termina con la presentación de las conclusiones. 


\section{La comprensión auditiva}

El desarrollo de la comprensión auditiva constituye un verdadero reto en el aprendizaje de una lengua extranjera. Muchos autores consideran que es la habilidad más difícil de desarrollar y que los docentes no le prestan suficiente atención.

Brown (1994) señala que en la década de los sesenta los enfoques para la enseñanza de lenguas estaban más preocupados por el desarrollo de la competencia oral de los estudiantes y, por ello, mostraban poco interés por el fomento de la habilidad de comprender lo que se escucha. Es así cómo, en ese momento, los ejercicios mecánicos de repetición constituían el centro de la actividad de enseñanza y aprendizaje del idioma.

El acto de escuchar implica un proceso psico-motor que se inicia en el momento de la recepción de las ondas sonoras a través del oído, que son transmitidas por los nervios como impulsos al cerebro, lo cual implica una serie de mecanismos cognitivos y afectivos.

Vandergrift (1997) define la comprensión auditiva como una habilidad que contribuye a la internalización de las reglas de la lengua y que facilita el desarrollo de otras competencias. Se puede considerar que la comprensión auditiva es aparentemente un proceso pasivo, sin embargo, investigadores como Vandergrifit (2002) han concluido que la habilidad auditiva es un proceso interactivo de reconocimiento, percepción y comprensión del input auditivo.

Vandergrift (2004) explica que la comprensión auditiva es una habilidad que no se puede observar, puesto que se trata de la habilidad menos explícita del lenguaje.

Rubin (citado por Brown, 1994) plantea que el desarrollo de la habilidad de comprensión auditiva está influenciada por factores como la edad, el género, la memoria, la atención e incluso las deficiencias del lenguaje. De acuerdo con lo anterior, el desarrollo de la competencia auditiva se convierte en una habilidad de alto refinamiento que requiere la atención del estudiante y la aplicación de estrategias que le permitan extraer el significado de lo que escucha. Es así como el autor plantea a los docentes de lenguas las siguientes preguntas: ¿qué hace el receptor cuando escucha?, ¿cuáles son los factores que permiten desarrollar la habilidad de escuchar?, ¿cuáles son las características de la comprensión auditiva?, ¿qué principios permiten desarrollar técnicas para mejorar la comprensión auditiva?, y ¿cuáles son las técnicas más comunes para enseñar el desarrollo de la habilidad de escuchar?

Al respecto, Richards (1983) explica ocho procesos que están presentes en la comprensión auditiva, entendida como un proceso de interacción:

- el receptor procesa lo que se conoce como discurso en bruto (raw speech) y guarda una imagen de este en la memoria a corto plazo, imagen que está constituida por frases, marcadores de cohesión y entonación, entre otros;

- el receptor determina el tipo de discurso que se está procesando, si se trata de una conversación, una transmisión de radio, un discurso presidencial u otro y, las formas de interpretación del mismo;
In this article, we present a brief contextualization about the listening comprehension, the notion of gamification, and its use in learning contexts. Next, we present the methodology and the obtained results in the mentioned application, and we summarize the article with the conclusions.

\section{Listening comprehension}

The development of the listening comprehension is a real challenge in the learning of a foreign language. Many authors think that it is the hardest ability to master and the teachers do not pay enough attention to that.

Brown (1994) considers that in the 60s, the approaches for the learning of languages were more focused on the development of the students' oral competences; consequently, they showed low interest by understand what was listened. For that reason, in that time, the mechanical exercises of repetition were the center of the teaching activity for the learning of a new language.

The act of listening entails a psychomotor process that starts in the moment the ear detects the sound waves being transmitted by the nerves as brain impulses. This implies a series of cognitive and affective mechanisms.

Vandergrift (1997) defines the listening comprehension as an ability that contributes to the internationalization of the language rules and eases the development of other competences. It is possible to consider that the listening comprehension is apparently, a passive process. However, researchers as Vandergrift have concluded that the listening ability is an interactive process of recognition, perception, and comprehension of the listening input.

Vandergrift (2004) explains that the listening comprehension is an ability not capable to be observed, since it is the least explicit ability of the language.

Rubin (cited by Brown, 1994) considers that the development of the listening comprehension activity is influenced by factors as age, gender, memory, attention, and even the language deficiencies. According to this, the development of the listening competence is a highly refined ability that requires the attention of the student and the application of strategies that allow him/her the extraction of the meaning of the listened. For that reason, the author lays out to the languages teachers the following questions: what does the receptor do when he/ she listens? Which are the factors that allow the development of the listening ability? Which are the features 
of the listening comprehension? What principles allow the development of techniques to improve the listening comprehension? And which are the most common techniques to teach the development of the listening ability?

In that regards, Richards (1983) explains 8 process that are present in the listening comprehension (understood as an interaction process):

- The receiver processes what is known as a raw speech and stores an image in the short-term memory, image made of phrases, cohesion and intonation markers, among others

- The receiver determines the speech type being processed: if that is a conversation, a radio transmission, a presidential speech, and the interpretation ways of it

- The receiver infers the transmitter objectives through the consideration of the speech types, its content, and the context behind it

- The receiver gathers relevant information about the context and content of the message. In this moment, the knowledge and experience of the receiver are assessed to perform cognitive operations to obtain an interpretation of the message

- The receiver assigns a literal significant to the message. This process involves a set of semantic interpretations to the received message

- The receiver assigns a significate according to the transmitter intentions, the possibility that misunderstandings arrive is generated in this phase of the process. A feature of the communication is the possibility to confirm or reformulate meanings between the participants of the exchange

- The receiver determines the information to be stored in the short and long term memory; and

- The receiver deletes of his/her memory the way the message was originally received.

The development process of the listening comprehension in the students of a foreign language - in this case, English- corresponds to the 8 phases described above. Consequently, we evidence that the listening ability is one of the most difficult to develop, since it is related with internal process performed by the subjects while the communicative exchange is performed. The languages teachers can use the following principles to develop strategies that allow the development of the listening comprehension of the students given the Brown (1994) principles. These principles include
- el receptor infiere los objetivos del emisor a través de la consideración de los tipos de discurso, su contenido y el contexto en el cual se elabora;

- el receptor recoge información relevante sobre el contexto y el contenido del mensaje, en este momento, el conocimiento y la experiencia del receptor entran en juego para realizar operaciones cognitivas, con el fin de lograr una interpretación del mensaje;

- el receptor asigna un significado literal al mensaje, este proceso involucra un conjunto de interpretaciones semánticas al mensaje recibido;

- el receptor asigna un significado de acuerdo con las intenciones del emisor, la posibilidad de que surjan malos entendidos se genera en esta fase del proceso, una característica de la comunicación es la posibilidad de confirmar o reformular significados entre los participantes del intercambio;

- el receptor determina qué información guardará en la memoria a corto y largo plazo; y

- el receptor borra de su memoria la forma como el mensaje fue originalmente recibido.

El proceso de desarrollo de la comprensión auditiva en los estudiantes de una lengua extranjera, en nuestro caso el inglés, comprende las ocho fases arriba descritas. Entonces, se evidencia que la habilidad de escuchar es una de las competencias más difíciles de desarrollar puesto que se trata de procesos internos que realizan los sujetos mientras se produce el intercambio comunicativo. Los docentes de lenguas pueden recurrir al uso de los siguientes principios para diseñar estrategias que permitan el desarrollo de la comprensión auditiva de los estudiantes según los planteamientos de Brown (1994). Dichos principios incluyen: la integración del currículo, el desarrollo de la motivación intrínseca del estudiante, el uso de materiales auténticos y el desarrollo de estrategias de escucha.

Adicionalmente, las características de las actividades de comprensión auditiva y las condiciones de desarrollo de éstas se consideran factores determinantes de la comprensión auditiva. Goh (2000) muestra que se ha incrementado el interés por investigar el rol de los diferentes tipos de instrucción y los materiales usados para el desarrollo de la comprensión auditiva.

Rosell-Aguilar (2007) ha encontrado que el uso de herramientas tecnológicas como el podcast ha favorecido, en buena medida, el desarrollo de la habilidad de escuchar, teniendo en cuenta que es posible extrapolar la práctica de la lengua a espacios y tiempos determinados por el estudiante.

Jordan (2012) plantea que la educación tradicional está avanzando hacia la transición de un modelo formal, institucionalizado y estático, hacia ambientes de aprendizaje de carácter innovador, dinámico y social, en los cuales el uso de elementos y mecánicas propias de los juegos contribuye al desempeño académico de los estudiantes y a la motivación hacia el aprendizaje. 


\section{Gamificaón}

La implementación del concepto de gamificación en educación surge como una nueva forma de crear experiencias significativas en contextos formales e informales de aprendizaje. Según Deterding, Dixon, Khaled, y Nacke (2003) el término gamificación nació en la industria de la comunicación digital en 2008, pero fue solo hasta 2010 que el término fue ampliamente conocido gracias a las conferencias y a los participantes de la industria que lo popularizaron.

Aunque hasta el momento no se le ha dado una definición académica al término, es claro que gamificación hace referencia a dos grandes conceptos: el primero corresponde al aumento de la adaptación social y la institucionalización de elementos de juegos video en la vida diaria; el segundo, se refiere a la idea de que los juegos de video son diseñados, más para el entretenimiento que para la utilidad, es decir, que los juegos pueden crear estados de experiencias deseables que motivan a los usuarios a permanecer enfocados en ellas.

Deterding, Sicart, Nacke, O'Hara, y Dixon (2011) definen el concepto de gamificación como el uso de elementos de diseño de juegos en contextos diferentes a los del juego. En gamificación se hace uso de la competencia instintiva que posee la mayoría de la gente para motivar y encausar comportamientos productivos.

Rollings y Adams (2003) definen un juego como una forma de entretenimiento interactivo o participativo. Puesto que el aprendizaje se concibe como un proceso participativo, la incorporación de elementos de los juegos en la educación constituye un elemento que provee grandes beneficios a dicha actividad. Es así como, para comprender cómo opera la gamificación en educación, es necesario entender los tres elementos claves de la construcción de juegos: los tipos de actividad, los mecanismos de recompensa y los mecanismos de seguimiento.

Los juegos son una experiencia tecnológica llamativa para todos los públicos (Borrero, Sanjuán \& Ramírez, 2015), su fin, a pesar de ello, en el caso de los juegos serios es distinto de entretener (Orozco, Baeza, Navarro, \& Llano, 2012). Cuando se centra un proceso de interacción en un juego, dice Abadía (2012) "las reglas deben ser establecidas rigurosamente, más cuando existen objetivos didácticos y de aprendizaje de por medio, como en el caso..."

Los tipos de actividad en los juegos, según Smith- Robbins (2011), están típicamente orientados hacia el logro de una meta; los objetivos son planteados de manera clara y se definen las condiciones para ganar y sobrepasar un número de obstáculos. De ésta manera, es posible establecer la similitud entre los juegos y la educación -los estudiantes o jugadores buscan cumplir con una tarea para alcanzar un objetivo o meta esperada-. El objetivo compartido de alcanzar metas por los juegos y la educación, es una razón fundamental para la implementación del concepto de gamificación en educación.

Algunos de los mecanismos de gamificación utilizados en educación son los de recompensa y seguimiento. the integration of the curriculum, the development of the intrinsic motivation of the student, the use of authentic materials, and the development of listening strategies.

Additionally, the features of the listening comprehension activities and their development conditions are considered as determining factors of the listening comprehension. Goh (2000) shows that an interest to research the role of the different instruction types and the employed materials for the development of the listening comprehension were increased.

Rosell-Aguilar (2007) has found that the use of technological tools as the podcast has helped the development of the listening ability, by considering that it is possible to extrapolate the language practice to spaces and times determined by the student.

Jordan (2012) suggests that the traditional education is advancing towards the transition from a formal, institutionalized and static model, to learning environments with innovative, dynamic, and social features where the use of elements and proper features of the games contribute to the academic performance of the students and encourages the motivation to the learning.

\section{Gamification}

The implementation of the gamification concept in the educational field arose as a new way to create meaningful experiences in formal and informal learning contexts. As per Deterding, Dixon, Khaled, and Nacke (2003), the gamification term was coined in the digital communication industry in 2008, but it was until 2010 that the term was widely known thanks to the conferences and the participants of the industry who made it popular.

Although, until now, no academic definition for the term has arisen, it is clear that the gamification can be associated to two large concepts: the increase of the social adaptation and institutionalization of video game elements in daily life, and the idea that the video games are designed more for the entertainment than for utility purposes; i.e., the games might create desirable experience states that motivate the users to stay focused on them.

Deterding, Sicart, Nacke, O'Hara, and Dixon (2011) define the gamification concept as the use of the game design elements in different contexts. In the gamification, the instinctive competence that most people have is used to encourage and charge productive behaviors. 
Rollings y Adams (2003) define a game as an interactive or participative entertainment. Given the fact that the learning is conceived as a participative process, the incorporation of game elements in the education is a topic that provides considerable benefits to that activity. Consequently, to understand how the gamification operates in the education, it is necessary to understand the three key elements in the construction of games: the activity types, the reward mechanisms, and the tracking mechanisms.

Games are a noteworthy technological experience for all the audiences (Borrero, Sanjuán \& Ramírez, 2015). Their purpose, in the case of serious games, is different than the entertainment (Orozco, Baeza, Navarro, \& Llano, 2012). When an interaction process is centered in a game, the rules must be clearly established, even more when didactic and learning objects exist, as Abadía (2012) mentions.

Citing data of Smith- Robbins (2011), the activity types in the games are typically oriented towards the achievement of a single goal; the objectives are planned in a clear way and the conditions to win and surpass several obstacles are defined. Here, it is possible to establish the similitude between the games and the education - the students or players seek to accomplish a task to achieve an expected objective/goal- - The shared objective of reaching goals in the games and in the education, is a fundamental reason for the implementation of the gamification concept in the education.

Some of the used gamification mechanisms in education are the reward and tracking ones.

There are three main reward mechanisms categories: scoreboards, prizes, and achievements. The first presents the reached scores by the participants per his/her progress level in the game. This table is normally used in competence activities, but it can also be used to stimulate the work group. The prizes are used as elements to increase the motivation (medals, trophies); whilst the achievements are publicly showed icons in the profiles of the participants that highlight activities made by one person. They point to satisfy the needs of a recognition.

The progress tracking mechanisms in the games are, somehow, analog to the following system in the education. This allow the guidance to the students about how to improve or advance in the development of their competences and the achievement of the proposed goals.
Hay tres categorías principales de mecanismos de recompensa: tablas de clasificación, premios y logros. La primera muestra los puntajes alcanzados por los participantes de acuerdo con su nivel de progreso en el juego, esta tabla es normalmente usada en actividades de competencia, pero también puede ser usada para estimular el trabajo en grupo; los premios son utilizados como elementos para aumentar la motivación (medallas, trofeos, placas); mientras que los logros son iconos mostrados públicamente en los perfiles de los participantes que resaltan actividades hechas por una persona, apuntan a satisfacer las necesidades de reconocimiento.

Los mecanismos de seguimiento del progreso en los juegos, por su parte, son de alguna manera análogos al sistema de seguimiento en educación. Este permite guiar a los estudiantes sobre cómo mejorar o avanzar en el desarrollo de sus competencias y el logro de las metas propuestas.

El concepto de gamificación en educación busca aumentar la motivación intrínseca de los estudiantes a través de proveer reconocimiento a los usuarios al completar actividades que a su vez conllevan al logro de una meta. Lo anterior tiene como efecto que los estudiantes estén más motivados a aprender.

La implementación del concepto de gamificación en educación también provee un marco para mejorar el uso de diferentes tipos de recursos que crea otras formas de aprendizaje, incorporando: audio, imágenes y textos en una experiencia singular, tal y como es el caso de la aplicación móvil utilizada en este proyecto de investigación: Doulingo.

Glover (2013) plantea que antes de implementar el concepto de gamificación en educación es necesario considerar las siguientes cuestiones:

- ¿es la motivación de los estudiantes realmente un problema?,

- ¿hay comportamientos que se deben incentivar?,

- ¿es posible gamificar actividades específicas?,

- ¿es posible crear una ruta de evaluación paralela?,

- ¿el uso de elementos de gamificación favorece a ciertos tipos de estudiantes?,

- ¿qué tipo de recompensas generarán mayor motivación en los estudiantes?,

- ¿algunas actividades requerirán una mayor disposición de tiempo que otras?, y

- ¿las recompensas son demasiado fáciles de obtener?

Las cuestiones arriba planteadas permiten mayor claridad sobre el proceso de implementación del concepto de gamificación en educación teniendo en cuenta que éste, como proceso que permite la generación de experiencias de aprendizaje participativas, se constituye en un marco de uso de diferentes tipos de recursos para activar el aprendizaje de los estudiantes.

\section{Metodología}

Uno de los objetivos del proyecto fue analizar el impacto de una aplicación móvil para el desarrollo de la competencia auditiva, como estrategia pedagógica para generar aprendizaje significativo en los estudiantes de nivel Al, de acuerdo con el 
marco común europeo para la enseñanza de lenguas (European Council, 2001). Para lograr este propósito, se implementó una prueba inicial y una prueba posterior al uso de la aplicación, con el fin de establecer el nivel de comprensión auditiva de los estudiantes, pre y post aplicación.

Aunque el proyecto de investigación fue de tipo cualitativo, para la presentación de los resultados se utilizaron elementos de carácter cuantitativo, tales como gráficos y tablas. A los estudiantes se les invitó a usar la aplicación Duolingo con el propósito de practicar la habilidad de escucha en el idioma inglés; luego, se aplicó una encuesta a cada alumno, con el fin de obtener resultados numéricos, sobre las bondades del uso de la aplicación móvil.

El diseño metodológico de esta investigación estuvo dirigido a demostrar la importancia que tiene el uso de las aplicaciones móviles para mejorar el aprendizaje del idioma Inglés, específicamente la comprensión auditiva.

La herramienta seleccionada fue Duolingo, en ello, aunque primó el hecho tratarse de una aplicación gratuita, en su selección se consideró además: el fácil acceso, su popularidad y su naturaleza, la aplicación, desarrollada por el profesor guatemalteco Luis Von Ahn (2011), se caracteriza por usar imágenes, sonidos, conversaciones y ejercicios de vocabulario, gramática y traducción, los cuales se presentan de manera interactiva a los usuarios.

El grupo seleccionado estuvo compuesto por siete hombres y cinco mujeres, con un promedio de edad de 19 años, quienes contaron con cuarenta minutos para contestar veinticinco preguntas subdivididas en cuatro secciones ( $a, b, c, d)$, con diferente nivel de complejidad. La prueba fue elaborada y adaptada tomando como base el texto Interchange intro teachers' resource book (Richards, Cory-Wright, \& Pianco, 2005). Esta prueba se aplicó, previo a la exposición de los estudiantes a Duolingo.

Los estudiantes del grupo escogido para el estudio estuvieron practicando con esta aplicación, de manera autónoma, por dos meses; al finalizar este periodo de práctica se procedió a aplicar de nuevo la prueba inicial, con el fin de establecer el beneficio del uso de la aplicación para el mejoramiento de la competencia auditiva en inglés.

Luego de usar la aplicación los estudiantes respondieron una encuesta de doce preguntas con el fin de obtener su opinión acerca del uso de las aplicaciones móviles en el proceso de aprendizaje de una lengua extranjera. Del conjunto de opiniones se puede establecer que el uso de la aplicación tuvo buena aceptación en el grupo.

\section{Resultados}

Como se indicó, se realizó una prueba estandarizada adaptada por los investigadores, que se aplicó al comienzo y al final del semestre. Con el fin de mostrar el beneficio de la aplicación móvil en el desarrollo de la competencia auditiva de los estudiantes, se mostrará aquellas secciones de la prueba donde se evidencia dicho progreso.
The gamification concept in education seeks to increase the intrinsic motivation of the students through the promotion of recognition to the users by completing activities, that carry on the achievement of a goal. This latter has as a main effect that the students are more motivated to learn.

The implementation of the gamification concept in education also provides a frame to improve the use of several types of resources that create other forms of learning. This latter by incorporating audio, images, and texts in a singular experience. This is the case of the mobile application used in this research project: Duolingo.

Glover (2013) considers that before implement the gamification concept in education, it is necessary to consider the following topics:

- Is the motivation of the students really a problem?

- Are there any behaviors needed to be incentivized?

- Is it possible to gamify specific activities?

- Is it possible to create a parallel evacuation route?

- Does the use of gamification elements helps certain types of students?

- What type of rewards will generate higher motivation in the students?

- Will some activities require a higher time disposition than others?

- Are the rewards too easy to obtain?

The above bullet points allow a higher clarity in the implementation process of the gamification in education, considering that as a process that allows the generation of participative learning experiences, it is a frame of use in different types of resources to activate the learning in the students.

\section{Methodology}

One of the objectives of the project was to analyze the impact of one mobile application for the development of the learning competence as a pedagogic strategy to generate significate learning in the Al level students in accordance to the common European frame for the teaching of languages (European Council, 2001). In order to achieve this purpose, we implemented an initial test and a posterior to the use of the application, to establish the level of listening comprehension of the students, before and after the use of the application. 
Although the research project was a qualitative one, for the presentation of the results we used quantitative elements, such as graphs and tables. We invited the students to use the Duolingo application with the purpose of practicing the listening ability in the English language. Then, we applied a survey to each student to obtain numeric results related with the advantages in the use of that application.

The methodological design of this research was entailed to demonstrate the importance the use of the mobile applications to improve the learning of the English language, specifically the listening comprehension.

The selected tool was - as mentioned before- Duolingo. We considered that for being a free application, and besides of the fact of the ease of access, its popularity, and nature. The application was developed by Luis von Ahn (2011) features the use of images, sounds, conversations, and vocabulary, grammar, and translating exercises presented in an interactive way to the users.

The selected group was composed of 7 men and 5 women, with an average age of 19. They had 40 minutes to answer 25 questions subdivided in four sections (a, b, c, d) with different complexity level. The test was elaborated and adapted taking as a basis the text named Interchange into teachers' resource book Richards, Cory-Wright, \& Pianco, 2005). This test was applied before the students use the Duolingo application.

The students of the selected group for the study were practicing with that application in an autonomous way by two months. When this time frame was over, we applied the initial test to establish the benefits of the application for the improvements in the listening comprehension of the English language.

After using the application, the students answered a 12-question survey to know their opinion about the use of the mobile applications in the learning process of a foreign language. We can establish that the use of the application had a good acceptation in the group.

\section{Results}

As we previously stated, we performed a standardized test adapted by the researchers applied at the beginning and the end of the semester. To show the benefits of the mobile application in the development of the listening comprehension of the students, we show the parts of the test where the progress is evident.
La Figura 1 muestra que el 42\% de los estudiantes contestó de manera correcta la sección 1 de la prueba y un 58\% de ellos la contestó de manera incorrecta. De lo anterior se deduce que un alto porcentaje de los estudiantes muestra deficiencias en el desarrollo de la competencia auditiva del inglés.

En la FIGURA 2 se observa la mejora de la habilidad de escucha de los estudiantes con un $100 \%$ de respuestas correctas en la primera sección de la prueba realizada luego de usar Duolingo. Lo anterior evidencia de manera contundente que el uso de la aplicación móvil favoreció el desarrollo de la competencia auditiva.

En la Figura 3 se observa que un alto porcentaje de los estudiantes mostró que no logra obtener un resultado correcto en la identificación de las actividades que se están realizando What are they doing?

Lo anterior, contrasta con lo que muestra la Figura 4, que corresponde al resultado de la misma pregunta, luego de que los estudiantes utilizaran la aplicación. El porcentaje de estudiantes que

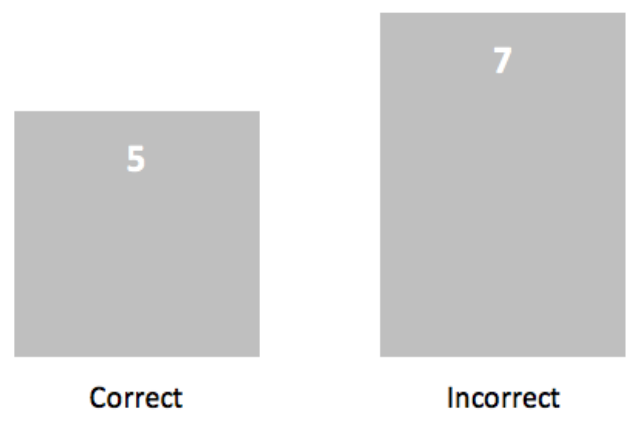

Figure 1. Listening 1 (inicial)

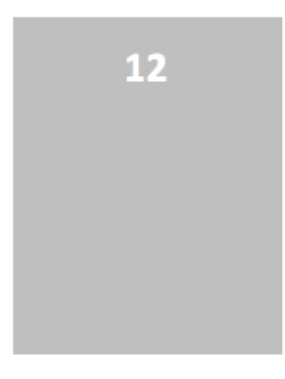

Correct

Incorrect

Figure 2. Listening 1 (final)

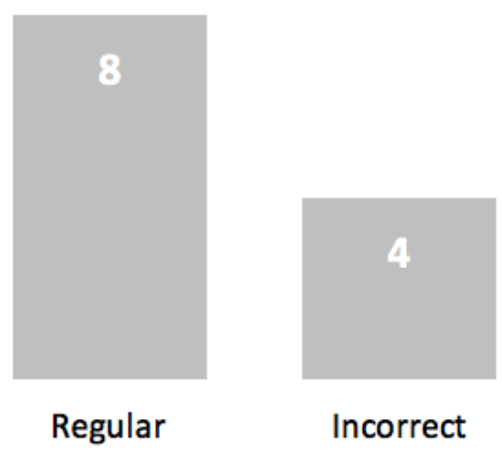

Figure 3. Listening 5 (inicial) 


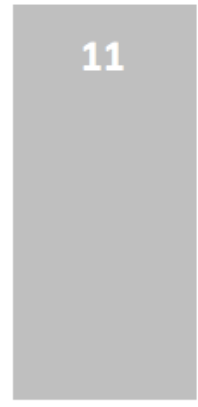

Correct

\section{Regular}

Figure 4. Listening 5 (final)

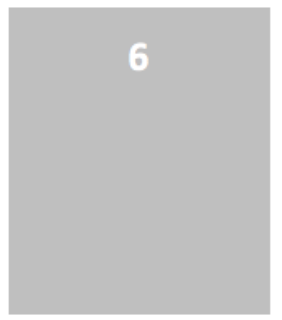

Correct

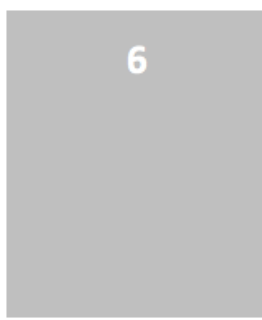

Incorrect
Figure 5. Listening 6

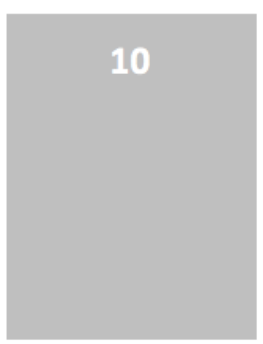

Correct

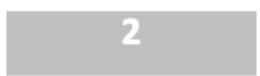

Incorrect
Figure 6. Listening 6 (final)

logró contestar de manera correcta todas las preguntas aumentó significativamente, pasó de cero a $92 \%$.

En la Figura 5 se presenta el resultado de los estudiantes en la prueba inicial en un ejercicio que consiste en identificar vocabulario relacionado con actividades de rutina. Los resultados muestran que la mitad del grupo acierta en el ejercicio de la prueba y e igual número no lo logra.

El resultado obtenido por los estudiantes luego de usar la aplicación muestra un incremento en el porcentaje de las respuestas correctas, 83\% frente a un 50\% en la prueba inicial (ver Figura 6).

De los resultados que arrojó la encuesta sobresale un aspecto de percepción, relacionado con el uso de tecnologías móviles para el aprendizaje de una lengua extranjera. En la Figura 7 se muestra el resultado de la opinión de los estudiantes frente a la pregunta: ¿En qué medida considera usted que las aplicaciones móviles le ayudan a aprender y practicar inglés? 75\% de los estudiantes considera que las aplicaciones móviles contribuyen al aprendizaje de la lengua extranjera, y solo el $25 \%$ opina que ayudan poco; nadie menciona que sean inútiles en algún grado.
Figure 1 shows that $42 \%$ of the students correctly answered the section 1 of the test and the remaining $58 \%$ responded incorrectly. From here, we can infer that a high percentage of the students presents deficiencies in the development of the listening comprehension of the English language.

In Figure 2, we observe the improve in the listening ability of the students with a $100 \%$ of correct answers in the first section of the test performed after the use of Duolingo. That is, the use of the mobile application helped improve the development of the listening comprehension in the students.

In Figure 3, we observe that a high percentage of the students is not able to obtain a correct result in the identification of the activities being performed in the What are they doing section.

From the results in the above graph, it is possible to infer that those results contrast with the shown in FIGURE 4 - the same question after the use of the application-. The percentage of students with correct answers is now $92 \%$.

In Figure 5, we present the results of the students in the initial test in an exercise consisting of identifying vocabulary related with daily activities. The results show that half of the group was correct in the tests and the other half did not.

The result obtained by the students after using the application show an increase in the percentage of the correct answers: $83 \%$ with regard to $50 \%$ in the initial test (see Figure 6).

From the results that the survey presented, we can highlight a perception aspect related with the use of the mobile technologies for the learning of a foreign language. In Figure 7, we show the students opinion to the question: how do you think the mobile applications help you learn and practice English? 75\% of the students consider that the mobile applications contribute to the learning of a foreign language and only the 25\% think that the contribution is low. There is no mention that the applications are useless at all.

\section{Discussion}

The use of mobile applications for the teaching and/ or learning of languages has increased in the last years. In the literature, it is possible to find articles and studies that show the benefit of the incorporation of the technology use and mobile applications in several academic 
topics in various institutions worldwide. To deep this, we have chosen five researches that are closely related to the study presented in this article.

Ramos \& Valderruten (2014) show that the use of wireless response technologies in English tests have a positive impact in the presentation of standardized tests of sufficiency in foreign languages. They also applied a survey to the students to know their opinion to the use of such technologies in the English classes, where the approval for their use was evident relative to the traditional classes. In general, the obtained results show affinity with our results, since the acceptation of the use of technologies in the learning of English and the positive impact in the development of the class.

On the other hand, González (2015) presented a survey where the objective was to show the integration of the technology as a significant tool for the teaching of English as a foreign language. He showed how the use of the technology significantly improves the quality of the classes and promotes the motivation towards the learning of the language.

The author addressed that it is common that some barriers still exist that do not allow the university professors use different technological tools. Although, the research is focused on the integration of the technology in diverse ways as the use of virtual platforms, e-mails, web pages, and power point presentations; it also includes the use of mobile devices as a strategy to maintain the interest in the learning of the foreign language through the use of the translator, the applications, games, and dictionary.

$90 \%$ of the people that was surveyed in the research of González (2015) pointed out their disposition to the use of the technology as a reinforcement tool in the learning of English; result that agrees with the one in the present study.

López \& Silva (2013) showed the most influence factors in the accepting of the mobile devices in the learning processes in higher education. This was the first research in Spain that presented quantitative results about students using mobile devices as a complement to their formation, besides of the factors influencing in the adoption of this learning method. On their results, they show that $75 \%$ of the students (from a sample of 411 ) use their mobile devices with some activity related with learning. This demonstrates that the students are taking the initiative and innovating in the ways of learning, i.e., the use

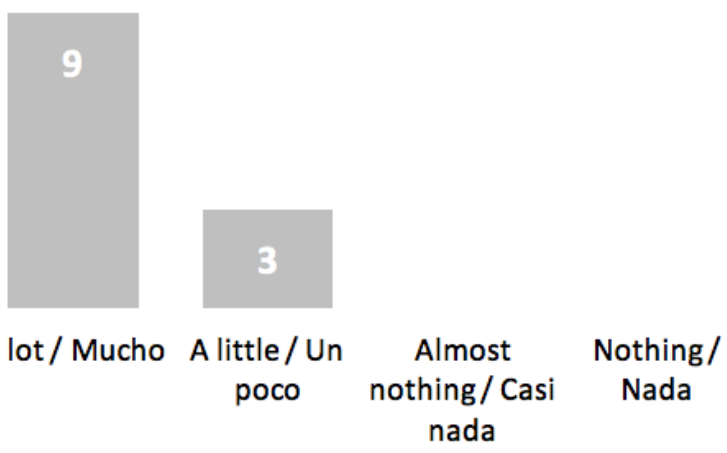

Figure 7. How much do you think that the use of this application helps to improve the listening comprehension in English? / Cuánto cree usted que el uso de esta aplicación le ayudó a mejorar su comprensión auditiva en inglés?

\section{Discusión}

El uso de aplicaciones móviles para la enseñanza y/o aprendizaje de idiomas se ha popularizado en los últimos años. En la literatura se encuentran artículos y estudios que muestran el beneficio de la incorporación del uso de tecnología y aplicaciones móviles en varios ámbitos académicos en diferentes instituciones a nivel mundial. Para efectos de la discusión, se han escogido cinco investigaciones que guardan estrecha relación con el estudio aquí presentado.

Ramos y Valderruten (2014) muestran que el uso de tecnologías inalámbricas de respuesta en exámenes de inglés logra un impacto positivo en la preparación de los estudiantes con miras a la presentación de pruebas estandarizadas de suficiencia en la lengua extranjera; esa investigación también aplicó una encuesta a los estudiantes para conocer su opinión sobre el uso de dicha tecnología en las clases de inglés en la cual se hizo evidente su apreciación sobre la marcada diferencia entre los cursos tradicionales y la clase de inglés en la que se implementó la tecnología inalámbrica. En general, los resultados obtenidos por ellos muestran afinidad con los resultados obtenidos por los investigadores en cuanto a la aceptación del uso de tecnologías en la clase de inglés y el impacto positivo en el desarrollo de las clases de lengua extranjera.

Por su parte González (2015), en un estudio cuyo objetivo fue mostrar la integración de la tecnología como herramienta significativa para en la enseñanza del inglés como lengua extranjera, mostró cómo el uso de la tecnología mejora significativamente la calidad de las clases y promueve la motivación hacia el aprendizaje del idioma.

El autor señaló que es común que aún existan barreras que impiden que los docentes universitarios utilicen diferentes formas de herramientas tecnológicas. Aunque la investigación realizada por él enfatiza la integración de la tecnología en diversas formas tales como: el uso de: plataformas virtuales, correos electrónicos, páginas web y presentaciones en Power Point, también incluye el uso de dispositivos móviles como una estrategia para mantener el interés por el aprendizaje de la lengua extranjera a través del uso del traductor, las aplicaciones y los juegos y diccionarios. 
El 90\% de quienes participaron en la investigación del profesor González (2015) indicó su disposición frente a la utilización de la tecnología como herramienta de refuerzo en su aprendizaje del inglés, resultado que coincide con el del presente estudio.

López y Silva (2013) mostraron los factores que inciden en la aceptación de los dispositivos móviles en los procesos de aprendizaje en educación superior. Esta investigación, la primera en España que presenta resultados cuantitativos sobre estudiantes que usan dispositivos móviles como complemento a su formación y los factores que influyen en la adopción de este método de aprendizaje, entre sus resultados muestra que el 75\% de los estudiantes (en una muestra de 411 estudiantes universitarios) utiliza sus dispositivos móviles con alguna actividad relacionada con el aprendizaje. Lo anterior demuestra que los estudiantes están tomando la iniciativa e innovando en nuevas formas de aprender, es decir que el uso de dispositivos móviles está fuertemente arraigado en sus hábitos de comportamiento y de aprendizaje.

En términos generales, los resultados obtenidos en su investigación por López y Silva (2013) coinciden con los hallazgos de la presente investigación en cuanto a la aceptación y el uso de aplicaciones móviles para complementar la formación universitaria. Cuando se consultó a los estudiantes acerca del uso de dispositivos móviles para este fin, un alto porcentaje de los estudiantes del grupo encuestado manifestó que el uso de aplicaciones móviles se constituye en una herramienta que les permite aprender o practicar la lengua extranjera lo cual, redunda en el mejoramiento de las competencias a desarrollar en el idioma.

Jung (2015) plantea que el rol de la tecnología móvil en educación, específicamente en enseñanza del inglés, se ha incrementado enormemente en la última década. Lo anterior se debe a que el uso de la tecnología móvil permite una buena conjunción con los objetivos de aprendizaje. Este tipo de tecnología cuenta con actividades que permiten que los estudiantes expandan sus experiencias de aprendizaje y exploren nuevas posibilidades.

El estudio realizado por Jung (2015) se considera un trabajo único sobre los factores que influyen en la enseñanza del inglés, específicamente investigando sobre la adopción de un modelo de implementación de tecnología móvil centrado en la perspectiva del estudiante. Su investigación y el presente estudio coinciden en las conclusiones acerca del uso de aplicaciones móviles para la enseñanza y aprendizaje de la lengua extranjera, particularmente en lo que respecta a la interacción de los estudiantes y la tecnología móvil, y a la percepción de los mismos sobre el uso de las aplicaciones móviles en el desarrollo de competencias específicas, como es el caso de la competencia auditiva.

El desempeño de los estudiantes que utilizaron la aplicación móvil -tecnología ampliamente aceptada por los estudiantesmejoró sustancialmente, como se evidencia en las figuras expuestas.

Adicionalmente, Gómez y Lazo (2015) exponen un estudio de caso relacionado con el uso potencial de aplicaciones móviles en el proceso de aprendizaje de estudiantes de posgrado. Su investigación tuvo como objetivo la construcción teórica de un modelo educomunicativo basado en aplicaciones móviles para el estudio y aprendizaje de una asignatura. Los autores of mobile devices is highly related with their behavior and learning habits.

In general terms, the obtained results in the research performed by López \& Silva (2013) are in accordance with the ones in our research in the acceptation and the use of mobile applications to complement the higher education. When the students were consulted about the use of mobile devices for that end, a high percentage manifested that the use of mobile applications is a tool that allow them to learn or practice the foreign language, which improves in the competences related with that language.

Jung (2015) proposes that the role of the mobile technology in the education - specifically in the teaching of the English language - has increased considerably in the last decade. This, due to the fact that the use of the mobile technology allows a good conjunction with the learning objectives. This type of technology has activities that allow the expansion of the learning experiences for the students and allows the exploration of new possibilities.

The study carried out by Jung (2015) is considered as a unique work related with the factors influencing the teaching of English, specifically researching in the adoption of a mobile technology implementation model centered in the student perspective. His research and ours agree with the conclusions about the use of mobile applications for the teaching and learning of a foreign language, particularly in the part related with the interaction of the students regarding the mobile technology and their perception about the use of mobile applications in the development of specific competences, as is the case of the listening competence.

The performance of the students who used the mobile application - widely used technology accepted by the students - was improved considerably as the graphs in the previous section show.

Additionally, Gómez \& Lazo (2015) expose a case study related with the potential of the mobile applications in the learning process of postgraduate students. Their research had as main objective the theoretical building of an "educommunicative" model based on mobile applications for the study and learning of a certain subject. The authors consider that the use of the applications in the educative contexts require, beyond the technology itself, a methodological design that entails experimentation, simulation, and game as facilitator elements of learning. 
Although the study of Gómez \& Lazo (2015) differs from our research on its general objective, both in their and our approaches, the mobile applications are a tool that improves the learning processes and require the dedicated participation of the students as main protagonists of such processes.

Rahimi \& Soleymani (2015) focused on researching the impact of the mobile technology and the listening comprehension in students of English as a foreign language. Their study used as sample a group of 52 students divided in two: experimental and control ones. Their results and the ones in our approach are compatible, since both demonstrate that the mobile technology has a positive effect in the improvement of the students listening ability. This is based on the particularities that mobile devices present and the ease of access the students must use the materials anytime, anywhere (especially outside the classroom). That is translated into portability, social interactivity, connectivity, and individuality. Furthermore, the features of the mobile technology use from the students allows to increase the motivation towards the learning of a foreign language.

\section{Conclusions}

The gamification concept applied to educative concepts allows the students to advance on their learning processes at their own pace, given the features of the mobile applications: easy and fast access, availability, and low cost.

The implementation of proper elements of the games in scholar contexts such as the learning of a foreign language are a novel aspect impacting positively the performance of the students. The use of mobile applications to develop a listening competence of the Al level students of the USC showed favorable results and evidenced the preference towards the use of these tools as a complement to the practice of the foreign language.

In general terms, we can conclude that the obtained results in this research project are similar to the ones in other national and international studies. The use of mobile applications in the learning process of a foreign language entails benefits in the development of competences, specifically in the listening comprehensio. ș consideran que el uso de aplicaciones en los contextos educativos requiere, más allá de la propia tecnología, un diseño metodológico que contemple experimentación, simulación y juego, como elementos facilitadores del aprendizaje.

Si bien, el estudio de Gómez y Lazo (2015) se diferencia de la presente investigación en cuanto a su objetivo general, en ambos casos el uso de las aplicaciones móviles constituye una herramienta que mejora los procesos de enseñanza y aprendizaje y requiere de la participación decidida de los estudiantes como sujetos protagonistas de dichos procesos.

Rahimi y Soleymani (2015) se enfocaron en investigar el impacto de la tecnología móvil y la comprensión auditiva de estudiantes de inglés como lengua extranjera. Su estudio tomó como muestra un grupo de cincuenta y dos estudiantes, dividido en dos, uno experimental, otro de control. Los resultados alcanzados por ellos y los obtenidos en la presente investigación son compatibles en cuanto demuestran que la tecnología móvil tiene un efecto positivo en el mejoramiento de la habilidad de escucha de los estudiantes. Lo anterior se sustenta en las particularidades que caracterizan a los dispositivos móviles y la facilidad de acceso con que cuentan los estudiantes para utilizar los materiales en cualquier momento y lugar, especialmente fuera del salón de clases, esto es: portabilidad, interactividad social, conectividad e individualidad. Además, las características del uso de la tecnología móvil por parte de los estudiantes permiten incrementar la motivación por el aprendizaje del idioma.

\section{Conclusiones}

El concepto de gamificación, cuando se aplica a contextos educativos, permite que los estudiantes avancen en su proceso de aprendizaje a su propio ritmo, dadas las características de las aplicaciones móviles: fácil y rápido acceso, disponibilidad y bajo costo.

La implementación de elementos propios de los juegos en contextos como el de la enseñanza de una lengua extranjera constituye un aspecto innovador que impacta de manera positiva el desempeño de los estudiantes. El uso de la aplicación móvil, con fines de desarrollar la competencia auditiva de los estudiantes de nivel Al de la USG, mostró resultados favorables y evidenció la preferencia hacia el uso de estas herramientas como complemento para la práctica de la lengua extranjera.

En términos generales se puede concluir que los resultados obtenidos en este proyecto de investigación son bastante similares a los hallazgos encontrados en otros estudios desarrollados a nivel nacional e internacional. El uso de las aplicaciones móviles en el proceso de aprendizaje de una lengua extranjera redunda en beneficios positivos en el desarrollo de competencias, específicamente en la mejora de la comprensión auditiva. ST 


\section{References / Referencias}

Abadía, I. (2012). Juegos serios para televisión digital interactiva: revisión de literatura y definiciones. Sistemas \& Telemática, 10(22), 149-157. doi:10.18046/syt.v10i22.1270

Borrero, F., Sanjuán, P., \& Ramírez, G. (2015). Técnicas de gamificación en el turismo, prueba de aplicación, Casa Museo Mosquera. Sistemas \& Telemática, 13(33), 63-76. doi:10.18046/syt.v13i33.2081

Brown, D. (1994). Teaching by principles: An interactive approach to language pedagogy [2nd ed.]. London, UK: Longman.

Deterding, S., Dixon, D., Khaled, R., \& Nacke, L. (2011a). From game design elements to gamefulness: defining gamification. In Proceedings of the 15th international academic MindTrek conference: Envisioning future media environments (pp. 9-15). New York, NY: ACM.

Deterding, S., Sicart, M., Nacke, L., O'Hara, K., \& Dixon, D. (2011b). Gamification: Using game-design elements in non-gaming contexts. In CHI'1 1 Extended Abstracts on Human Factors in Computing Systems (pp. 2425-2428). New York, NY: ACM.

European Council. (2001). Common European framework for languages: Learning, teaching, assessment. Strasbourg, France: Council for Cultural Cooperation.

Glover, I. (2013). Play as you learn: Gamification as a technique for motivating learners. In: Proceedings of World Conference on Educational Multimedia, Hypermedia and Telecommunications 2013. Chesapeake, VA, AACE.

Goh, C. C. (2000). A cognitive perspective on language learners' listening comprehension problems. System, 28, 55-75. doi: 10.1016/S0346-251X(99)00060-3

Gómez, C. \& Lazo, C. (2015). Modelo de integración educomunicativa de "apps" móviles para la enseñanza y aprendizaje. Revista de Medios y Educación, 46, 137-153.

González, H. (2015). La integración de la tecnología como herramienta significativa en la enseñanza de inglés como lengua extranjera. Revista Horizontes Pedagógicos, 17(1), 53-66.

Jordan, P. (2012). Games and learning: Gamification in formal educational settings. Retrieved from: https://pdfs.semanticscholar.org/b1e9/042863e712d13cb788bcd807d51267d51017.pdf

Jung, H. (2015). Fostering an English teaching environment: Factors influencing English as a foreign language teacher's adoption of mobile learning. Informatics in Education, 14(2), 219-241.

López, F. \& Silva, M. (2013). Factores que inciden en la aceptación de los dispositivos móviles para el aprendizaje en educación superior. Estudios sobre Educación, 30, 175-195.

Orozco, A.M., Baeza, D., Navarro, A., \& Llano, G. (2012). Del videojuego a la realidad: sistema interactivo para la seguridad vial. Sistemas \& Telemática, 10(22), 37-50. doi: 10.18046/syt.v10i22.1259.

Rahimi, M. \& Soleymani, E. (2015). The impact of mobile learning on listening anxiety and listening comprehension. English Language Teaching, 8(10), 152-161.

Ramos, L. \& Valderruten, A (2014). Beneficios del uso de tecnologías inalámbricas de respuesta en exámenes de inglés. [Con] textos, 3(12), 45-54. doi: 10.21774/ctx.v3i12.477

Richards, J. (1983). Listening comprehension: Approach, design, procedure. TESOL Quarterly, 17(2), 219-240.

Richards, J., Cory-Wright, K., \& Pianco, S. (2005). Interchange intro teachers' resource book [3rd ed.]. Cambridge, UK: Cambridge University Press.

Rollings, A. \& Adams, E. (2003). On game design. Indianapolis, IN: New Riders.

Rosell-Aguilar, F. (2007). Top of the pods-in search of a podcasting "Pedagogy" for language learning. Computer Assisted Language Learning, 20, 471-492. doi:10.1080/09588220701746047

Smith- Robbins (2011). This game sucks: How to improve the gamification of education. Educause Review, 46(1), 58-59.

Vandergrift, L. (1997). The comprehension strategies of second language (French) listeners: A descriptive study. Foreign Language Annals, 30(3), 387-409. doi:10.1111/j.1944-9720.1997.tb02362.x

Vandergrift, L. (2004). Listening to learn or learning to listen? Annual Review of Applied Linguistics, 24, 3-25. doi:10.1017/ S0267190504000017

Vandergrift, L., (2002). Listening: Theory and practice in modern foreign language competence. Retrieved from: https://www. Ilas.ac.uk//resources/gpg/67

von Ahn, L. (2011). Utilizando el poder de millones de mentes humanas [video: TED Rio de la Plata, 2011]. Retrieved from: https://www.youtube.com/watch?v=x1ShVyBm8GU 


\section{CURRICULUM VITAE}

Judith Bustillo. BA on Modern Languages from the Universidad Santiago de Cali (Colombia) and with a Technical degree in Junior High School Education of the Corporación Instituto de Artes y Ciencias (Barranquilla, Colombia) / Licenciada en Lenguas Modernas de la Universidad Santiago de Cali (Colombia) y Tecnóloga en Educación Pre-escolar de la Corporación Instituto de Artes y Ciencias [CIAC] (Barranquilla, Colombia).

Claribel Rivera. BA on Foreign Languages English-French and Specialist in the Teaching of English from the Universidad Santiago de Cali (Colombia) / Licenciada en Lenguas Extranjeras Inglés-Francés y Especialista en Enseñanza de Inglés de la Universidad Santiago de Cali (Colombia).

Juan Genaro Guzmán. BA on Foreign Languages English-French and Specialist in Teaching of English from the Universidad Santiago de Cali (Colombia) / Licenciado en Lenguas Extranjeras Inglés-Francés y Especialista en Enseñanza de Inglés de la Universidad Santiago de Cali (Colombia).

Lizeth Ramos Acosta. BA on Modern Languages from the Universidad del Valle (Cali, Colombia); Specialist in Teaching for Higher Education and Master in Higher Education from the Universidad Santiago de Cali. Coauthor of "In Context" books. Teacher and Director of the Specialization in the Learning of English at the Universidad Santiago de Cali, with seventeen years of experience in university teaching / Licenciada en Lenguas Modernas de la Universidad del Valle (Cali, Colombia); y Especialista en Docencia para la Educación Superior y Magister en Educación Superior de la Universidad Santiago de Cali. Coautora de los volúmenes 1 y 2 del texto In Context. Cuenta con diecisiete años de experiencia docente universitaria. Es docente y Directora de la Especialización en Enseñanza de Inglés de la Universidad Santiago de Cali. 